\title{
AGRIBISNIS LORJUK (Solen grensalis) DALAM ANALISIS TARGETING DAN POSITIONING di KABUPATEN PAMEKASAN
}

\author{
Agribusiness Lorjuk (Solen Grensalis) In Analysis Targeting And Positioning \\ In Pamekasan
}

Endang Tri Wahyurini

Program Studi Agrobisnis Perikanan Universitas Islam Madura

Email; endangtriwahyurinis.pi_rini@yahoo.co.id

\begin{abstract}
This study aimed to analyze the positioning and targeting and commodities lorjuk. Lorjuk is the one commodity that is unique and of high economic value.Determination of the respondents in this research is purposive sampling method or methods to determine the respondents deliberately namely the producers' lorjuk "the seller" lorjuk "and consumers" lorjuk ". This research was conducted for three months in Pamekasan. The data has been analyzed using cluster analysis. As for the conclusions obtained are as follows segmentation lorjuk according to the manufacturers point of view is that lorjuk is a source of income is still in demand by consumers-specific consumer. Manufacturers must perform in order for product diversification lorjuk sold survive in the market. While lorjuk according to the consumer's viewpoint is that lorjuk The discussion on cluster 1 showed that respondents who chose the attributes taste good and tasty, high protein and a healthy diet as much as 33.3\%, while choosing attributes like seafood, prestige and image nice as much as $23.3 \%$ and the select attribute can be made nibbles, made souvenir s and treats for the guests as much as $43.3 \%$. This shows that market segmentation lorjuk to consumers more dominated by reason as a snack food, for souvenirs and to treat guests at home that is equal to $43.3 \%$.
\end{abstract}

Key words : agribisnis, lorjuk, targeting dan positioning

\begin{abstract}
ABSTRAK
Penelitian ini dimaksudkan untuk menganalisis positioning dan targeting dan komoditas lorjuk. Lorjuk merupakan salah satu komoditas perikanan yang unik dan bernilai ekonomis tinggi. Penentuan responden dalam penelitian ini adalah dengan metode purposive sampling atau metode penentuan responden dengan sengaja yaitu para produsen lorjuk yaitu penjual lorjuk serta konsumen lorjuk. Penelitian ini dilakukan selama tiga bulan di Kabupaten Pamekasan. Data yang sudah terkumpul dianalisis menggunakan analisis cluster. Hasil penelitian menunjukkan bahwa segmentasi lorjuk menurut sudut pandang produsen adalah bahwa lorjuk merupakan sumber penghasilan yang masih diminati oleh konsumen- konsumen tertentu. Produsen harus melakukan difersifikasi agar produk lorjuk yang dijual bisa bertahan di pasaran. Sedangkan lorjuk menurut sudut pandang konsumen adalah bahwa lorjuk Pembahasan tentang cluster 1 menunjukkan bahwa responden yang memilih atribut rasa enak dan gurih, protein tinggi dan merupakan makanan sehat sebanyak 33,3\%, sedangkan yang memilih atribut suka seafood, prestise dan image yang bagus sebanyak 23,3\% dan yang memilih atribut bisa dibuat camilan, dibuat oleh-oleh dan di buat suguhan tamu sebanyak 43,3\%. Hal ini menunjukkan bahwa segmentasi pasar lorjuk untuk konsumen lebih didominasi karena alasan sebagai makanan camilan, untuk oleh-oleh dan untuk suguhan tamu dirumah yaitu sebesar $43,3 \%$.
\end{abstract}

Kata kunci : agribisnis, lorjuk, targeting dan positioning 


\section{PENDAHULUAN}

Potensi lestari sumber daya ikan laut Indonesia mencapai sekitar 6,26 juta ton per tahun atau $7 \%$ dari total potensi lestari sumber daya ikan laut dunia dengan tingkat pemanfaatan oleh nelayan mencapai 5,6 juta ton ( Dahuri et al., 2006). Lorjuk merupakan istilah lain dari kerang pisau yang digunakan oleh sebagian besar masyarakat Jawa Timur. Beberapa jenis makanan dan snack berbahan baku lorjuk yang telah dikreasikan oleh masyarakat antara lain kacang goreng lorjuk, soto lorjuk, petis lorjuk, bothok lorjuk dan rengginang lorjuk. Anonymous (2010) lorjuk (Solen vaginalis) adalah salah satu jenis kekerangan (Pelecypoda) yang mempunyai nilai ekonomis tinggi. lorjuk merupakan salah satu komoditas perikanan yang memiliki keunikan tersendiri. lorjuk dapat ditemukan dipinggir pantai, namun tidak setiap pantai dapat ditemukan lorjuk, hanya daerah-daerah tertentu saja. Lorjuk adalah jenis kerang bambu yang memiliki kandungan protein yang tinggi. Kabupaten Pamekasan merupakan salah satu penghasil lorjuk. lorjuk merupakan salah satu produk agribisnis yang dikonsumsi sebagai makanan ringan, dan juga sebagai campuran makanan ringan lain seperti rengginang dan kacang goreng. Meskipun harganya mahal lorjuk banyak digemari oleh masyarakat, bahkan sering dijadikan oleh-oleh khas Pamekasan.

Penjualan lorjuk di toko ataupun supermarket cukup lambat, hal ini karena selain harganya yang sangat mahal juga tidak semua orang menyukai dan mampu membeli lorjuk tersebut. Meskipun harganya mahal namun masih banyak masyarakat yang menyukai kerang ini. Komoditas premium ini memiliki tempat tersendiri di hati konsumennya.

Berdasarkan hal tersebut maka permasalahan pada penelitian ini yaitu bagaimana positioning dan targeting lorjuk di Kabupaten Pamekasan. Adapun tujuannya adalah untuk membahas dan menganalisis mengenai target dan positioning lorjuk di Kabupaten Pamekasan.

\section{METODE PENELITIAN}

\section{Tempat dan waktu}

Galis $\begin{array}{ccc}\text { Penelitian dilakukan di Kecamatan } \\ \text { dan Pademawu }\end{array}$ Pamekasan, Madura. Penentuan lokasi secara sengaja (purposive) dilakukan $\mathrm{di}$ Kabupaten Pamekasan dengan pertimbangan bahwa Kabupaten Pamekasan merupakan salah satu daerah penghasil lorjuk terbanyak di Pulau Madura. . Penelitian dilaksanakan selama 5 bulan yaitu pada bulan Januari sampai Mei 2016.

\section{Metode}

Penelitian ini menggunakan penelitian deskriptif analistis atau penelitian Eksploratif.Untuk memperoleh data, baik data primer maupun data sekunder dilakukan dengan cara : Wawancara dengan para responden menggunakan daftar pertanyaan (kuisioner) yang sudah dipersiapkan. Data sekunder untuk memberikan gambaran umum penelitian yang didapatkan dari berbagai sumber yaitu dengan Badan Pusat Statistik, pemerintah daerah dan Kecamatan Galis dan Kecamatan Pademawu serta instansi-instansi terkait. Yaitu dengan cara mencari literatur yang relevan mengenai agribisnis lorjuk serta positioning dan targetnya.

Populasi dalam penelitian ini adalah para nelayan di daerah sentral penghasil lorjuk yang ada di Kabupaten Pamekasan yang terdiri dari 2 wilayah kecamatan yaitu Kecamatan Galis dan Kecamatan Pademawu. Penentuan lokasi sampling diambil secara sengaja (purposive) yaitu di 2 wilayah kecamatan tersebut. Respondennya adalah , pengepul dan pengolah lorjuk (produsen), toko penjual lorjuk. Untuk berjumlah masing-masing 10 orang sedangkan untuk pengepul dan pengolah lorjuk tiap kecamatan diambil 3 responden sedangkan untuk "toko penjual lorjuk diambil 10. Sedangkan untuk pembeli 
lorjuk (konsumen lorjuk) berjumlah 10 orang.

Sedangkan untuk menganalisis positioning lorjuk yaitu dengan alat analisis Multi Dimensional Scaling (MDS) dan dan Correspondece Analysis (CA) (analisis koresponden) merupakan suatu teknik eksplorasi yang didesain untuk menganalisis dua variabel sederhana dan multi variabel di dalam tabel untuk mengukur kemiripan antara baris dan kolom. Pada analisis koresponden tidak dilakukan reduksi variabel atau pembuatan cluster tetapi dilakukan pembanding antara pesaing. Analisis koresponden akan menggambarkan posisi produk lorjuk terhadap produkproduk yang memiliki kemiripan dengannya seperti teripang (rung terung).

\section{HASIL DAN PEMBAHASAN}

Kabupaten Pamekasan merupakan salah satu daerah terluas di Pulau Madura dan mempunyai wilayah pesisir yang luas. Daerah pesisir Pamekasan memiliki karakteristik yaitu adanya fenomena dimana pada lokasi-lokasi dekat pantai, dengan kedalaman sumur yang relatif rendah tetapi masih memiliki kualitas air tawar yang sangat baik dan dipergunakan masyarakat untuk konsumsi sehari-hari.

Secara geografis Pamekasan merupakan bagian dari wilayah propinsi Jawa Timur yang terletak di sebelah timur Pulau Jawa. Pamekasan adalah salah satu Kabupaten di kawasan Pulau Madura yang memiliki luas $729.30 \mathrm{~km} 2$, tepatnya pada koordinat $6^{\circ} 51-7^{\circ} 31 \mathrm{LS}$ dan $113^{\circ} 19-113^{\circ} 58$ BT. Secara demografis, berdasarkan data BPS (2016) jumlah penduduk Pamekasan sebanyak 795.918 jiwa. Dengan kepadatan penduduk per $\mathrm{km}^{2}$ cukup bervariatif. Secara administrative Kabupaten Pamekasan terdiri dari 13 Kecamatan dan 189 Desa/ Kelurahan (BPS Pamekasan, 2016).

Kecamatan Pademawu merupakan salah satu dari 13 kecamatan yang terdapat di Kabupaten Pamekasan, Madura. Luas Kecamatan Pademawu mencapai 7.189 Ha. Terdiri dari 22 desa yang Posisinya sebelah timur berbatasan dengan Kecamatan Galis, sebelah barat dan utara berbatasan dengan Kecamatan Pamekasan serta sebelah selatan berbatasan dengan kecamatan Tlanakan dan Selat Madura. Jarak Kecamatan Pademawu ke kota Pamekasan sekitar $10 \mathrm{Km}$ dan bisa ditempuh selama 0,5 jam. Di Kecamatan Pademawu ada beberapa desa yang memiliki potensi dalam bidang perikanan terutama untuk komoditas lorjuk. Di beberapa Desa tersebut dapat ditemui para produsen lorjuk, yaitu para pencari, pengepul dan pengolah lorjuk mereka tinggal di Desa Pademawu Timur dan Desa Tanjung. Namun yang lebih mendominasi adalah Desa Pademawu Timur, sehingga dalam penelitian ini lebih difokuskan di Desa Pademawu Timur.

Kecamatan Galis Kabupaten Pamekasan merupakan salah satu dari 13 kecamatan yang terdapat di Kabupaten Pamekasan, Madura. Luas Kecamatan Galis mencapai 3.186 Ha. Terdiri dari 10 Desa yang Posisi geografis terletak berbatasan langsung dengan Kecamatan Pademawu di sebelah Barat dan Selatan, sebelah Utara berbatasan dengan Kecamatan Larangan sedangkan untuk sebelah Timur berbatasan langsung dengan Selat Madura. (Anonymous, 2016). Kecamatan Galis Kabupaten Pamekasan yang daerah sebelah Timur berbatasan langsung dengan Selat Madura maka mayoritas penduduk di sekitar daerah pesisir tersebut banyak yang menjadi nelayan maupun petani garam. Wilayah pesisir di Kecamatan Galis kondisi penduduknya cukup baik hal ini terlihat dari aktifitas mereka yang cukup dinamis. Banyak kegiatan ekonomi yang mereka lakukan sehingga hampir tidak ada penduduk yang menganggur. Beberapa usaha dalam bidang perikanan yang bisa ditemukan di Kecamatan Galis ini adalah pengolahan krupuk, pengupasan kulit rajungan, pemindangan dan pengolahan lorjuk. Beberapa Desa yang memiliki potensi perikanan terutama lorjuk adalah Desa Polagan dan Desa Galis.

Responden yang digunakan dalam penelitian ini adalah para produsen dan 
konsumen lorjuk di Kabupaten Pamekasan. Adapun produsen yang dimaksud adalah para pencari lorjuk, para pengepul dan pengolah lorjuk serta penjual lorjuk, sedangkan konsumen adalah para pembeli dan pengkonsumsi lorjuk.

\section{Keragaan Usaha lorjuk}

Kerang yang satu ini memang bentuknya sedikit berbeda dengan kerang kebanyakan. Ia memiliki cangkang yang beruas-ruas mirip seperti bambu. Dengan rasanya yang khas ia pun bisa dibuat menjadi beragam olahan.

Masyarakat Jawa Timur dan Madura, kerang bambu yang dikenal juga memiliki nama Razor clams ini dikenal dengan lorjuk. Ia merupakan termasuk jenis kerang yang banyak terdapat di perairan atau pantai pesisir pulau Madura.

Kerang bambu ini berbentuk kecil panjang yang biasa hidup di pesisir pantai yang berlumpur. Biota yang termasuk ordo Veneroida ini memiliki cangkang berwarna kecoklatan. Bagian cangkang yang agak putih dilengkapi garis-garis coklat kehijauan, membuat biota ini sekilas mirip dengan bilah bambo. Di jelaskan juga oleh Baron et al. (2004) dalam Hidayat (2012) bahwa Ensis (lorjuk) hidup dengan membuat lubang (meliang) dan membenamkan diri di dalam pasir. Siphon pendek yang dimiliki biota ini akan berada di atas permukaan substrat saat tergenang air untuk mencari makan Hasil penelitian yang dilaporkan oleh Baron et al. (2004) dalam Hidayat (2012) menunjukkan bahwa Ensis tidak hanya hidup meliang di substrat, ternyata biota ini mampu merayap di permukaan substrat dan berenang. Diduga bahwa Ensis mampu bergerak aktif untuk mencari substrat yang sesuai dengan keinginannya.

Keberadaan atau ketersediaan lorjuk sangat dipengaruhi oleh luas area pencarian, lamanya pasang surut air laut dan ketrampilan pencari lorjuk dalam memburu atau mencari lorjuk.

Siklus musim lorjuk umumnya 1-2 bulan sehingga dalam 1 tahun terdapat 3 kali musim. Faktor musim sangat berpengaruh terhadap hasil tangkapan nelayan. Faktanya saat ini jumlah lorjuk kian menurun akibat penangkapan yang dilakukan terus menerus. Untuk mengetahui keberadaan lorjuk dengan cara melihat adanya tanda gundukan tanah atau jejak khusus yang biasa ditinggalkan oleh lorjuk sehingga para pencari lorjuk bisa dengan mudah mengenalinya.

Tabel 1. Kandungan gizi kerang pisau atau lorjuk (Solen spp)

\begin{tabular}{cccccc}
\hline \multirow{2}{*}{ Jenis gizi } & $\begin{array}{c}\text { Basis basah } \\
(\mathrm{bb})\end{array}$ & $\begin{array}{c}\text { Basis } \\
\text { kering (bk) }\end{array}$ & \multicolumn{2}{c}{ AKG (19-20th) } & Satuan \\
\cline { 4 - 5 } & & & Pria & Wanita & \\
\hline Kalori & $61,84 \mathrm{kkal}$ & $349,66 \mathrm{kal}$ & 2550 & 1900 & Kkal/hari \\
\hline Protein & $9,79 \%$ & $55,34 \%$ & 50 & 42 & g/hari \\
\hline Karbohidrat & $4,95 \%$ & $27,98 \%$ & 130 & 100 & g/kap/hari \\
\hline Abu & $0,32 \%$ & $1,82 \%$ & 54 & 54 & g/hari \\
\hline Air & $82,63 \%$ & $14,87 \%$ & $\sim$ & $\sim$ & $\sim$ \\
\hline
\end{tabular}

Sumber : Nurjanah et al. (2008) dalam Anonymous (2012) 
Komposisi kimia kerang sangat beraneka ragam. Hal ini dapat tergantung pada spesies, jenis kelamin, umur, musim, dan habitat. lorjuk merupakan makanan seafood yang bernilai gizi tinggi seperti seperti dalam Tabel 1 berikut ini.

Pengolahan lorjuk biasanya disajikan dalam bentuk olahan dan untuk menghasilkannya membutuhkan beberapa proses tahapan sebagai berikut:

Lorjuk segar hasil tangkapan dicuci untuk membuang pasir laut. Lorjuk yang telah bersih kemudian direbus selama 1,5 jam hingga kulit/cangkangnya mengelupas sendiri. Selanjutnya lorjuk beserta kulitnya tersebut dijemur selama 4 jam. Setelah kering daging lorjuk dipisahkan dari kulitnya. Keringkan kembali daging utuh lorjuk selama 6 jam. Setelah itu daging lorjuk yang benar-benar kering tersebut bisa dipasarkan ataupun diolah lebih lanjut. Untuk pengolahan lanjutan, biasanya cukup digoreng dengan sedikit penambahan gula dan garam untuk menghasilkan rasa yang lebih gurih dan renyah. (Inovea, 2010).

\section{Pola Tangkapan (Musim Pencarian lorjuk)}

Lorjuk merupakan komoditas perikanan yang memiliki daya tarik dan keunikan tersendiri. Lorjuk memiliki rasa yang enak dan khas, tetapi ternyata keberadaannya tidak bisa ditemukan secara mudah. Untuk mendapatkan kerang bambu ini biasanya masyarakat Madura memanfaatkan laut saat surut. Kemudian mereka berburu lorjuk yang terjebak dalam sedimen laut dengan menggunakan peralatan yang sederhana yaitu linggis dan ember plastik.

Mencari lorjuk di pesisir pantai Madura biasanya dilakukan secara bersamaan dan kadang berkelompok. Orang memburu atau mencari lorjuk ini biasanya di pagi dan sore hari saat air laut surut dan sebagian besar merupakan kaum ibu yang memang tidak bisa melaut.

Penangkapan lorjuk dilakukan ketika subuh dan siang hari. harus menyiapkan alat berupa rajang ( bahasa lokal Madura) atau linggis. Selain itu, juga mengenakan pakaian tebal untuk menghindari sengatan matahari.

Namun berbeda halnya dengan yang disampaikan oleh Benjamin ( 2011) bahwa beberapa tahun terakhir, kelompok nelayan yang ada disekitar Pantai Kenjeran Surabaya menemukan teknik baru untuk mendapatkan kerang pisau ini dalam jumlah banyak. Nelayan yang pada saat itu menggunakan alat tangkap bernama "Kerok - kerok" yang berfungsi sebagai penggali pasir, kemudian beralih menggunakan batu gamping dan sabun. Dengan cara menaburkan serpihan batu gamping dan air sabun di area fishing ground (biasanya berjarak 500 - 1000 meter dari pinggir pantai) dan dilakukan saat air laut pasang. Lalu menunggu dengan waktu yang tidak terlalu lama, Lorjuk ini akan muncul sendiri ke atas permukaan air laut, sehingga nelayan bisa dengan mudah mengumpulkannya. Dengan teknik ini nelayan bisa mengumpulkan $50 \mathrm{~kg}$ tiap kali tebar, sedangkan kalau menggunakan alat tradisional nelayan hanya bisa mendapatkan $3-4 \mathrm{~kg}$ tiap kali tangkap. Namun jika cara ini dicermati maka akan menimbulkan dampak punahnya lorjuk di Pantai Kenjeran Surabaya.

\section{Target Pasar lorjuk}

Target pasar tidak bisa dilepaskan dari segmentasi dan positioning, dalam hal menentukan target pasar lorjuk perlu media yang dapat digunakan untuk menjangkau kelompok atau segmen tertentu yang akan dituju. Yang dilakukan untuk menentukan target pasar lorjuk adalah dengan menyeleksi pasar atau tempat yang digunakan untuk menjual lorjuk tersebut. Sehingga dapat diketahui segmen mana yang nantinya menjadi sasaran bagi produk lorjuk.

Hasil analisis data dan mengidentifikasinya untuk target pasar lorjuk dan maka ditentukan target pasar lorjuk seperti pada Tabel berikut ini. 
Tabel 2. Target Pasar bagi lorjuk berdasarkan Geografi dan Demografi

\begin{tabular}{|c|c|c|c|}
\hline No & Variabel & Indikator & Target Pasar \\
\hline \multirow[t]{4}{*}{1} & Geografi & & \\
\hline & & Tempat Tinggal & $\begin{array}{l}\text { Di Komplek Perumahan, di kota,di } \\
\text { desa,dalam kota, luar kota }\end{array}$ \\
\hline & & Kota & $\begin{array}{l}\text { Pamekasan, Sumenep, Sampang } \\
\text { dan Bangkalan. }\end{array}$ \\
\hline & & Pendatang & Wisatawan, tamu luar kota \\
\hline \multirow[t]{6}{*}{2} & Demografi & & \\
\hline & & Usia & Rata-rata antara $20 \mathrm{Th}-50 \mathrm{Th}$ \\
\hline & & Jenis Kelamin & Perempuan dan Laki-laki \\
\hline & & Pendidikan & $\begin{array}{l}\text { Mayoritas dari SMU sampai } \\
\text { sarjana }\end{array}$ \\
\hline & & Penghasilan & $\begin{array}{l}\text { Rata-rata Rp. } 1.000 .000,00-R p \\
5.000 .000,00 \text { per bulan }\end{array}$ \\
\hline & & Profesi & $\begin{array}{l}\text { Guru, Dosen, PNS(Gol III keatas) } \\
\text { wiraswasta, pengusaha,dll. }\end{array}$ \\
\hline
\end{tabular}

Sumber: Data Primer Diolah (2016)

Dari tabel diatas diperoleh hasil bahwa target pasar lorjuk adalah masyarakat yang umumnya secara geografinya bertempat tinggal di Komplek Perumahan, di kota,di desa,dalam kota Pamekasan dan luar kota. Sedangkan secara demografi target pasar lorjuk adalah masyarakat pada usia rata-rata antara $20-50$ Th. Jenis Kelamin Perempuan dan Laki-laki. Pendidikan mayoritas mulai dari SMU sampai sarjana. Dengan tingkat penghasilan mayoritas adalah antara Rp. 1.000.000,00 Rp 5.000.000,00 per bulan. Target pasar lorjuk tersebut ditetapkan dengan asumsi bahwa pembeli dan konsumen lorjuk adalah masyarakat yang memang sudah berkecukupan dalam memenuhi kebutuhan pokok hidupnya. Sehingga mereka sudah memikirkan tentang kebutuhan sekunder dan tersiernya. Hal ini sesuai dengan tujuan target pasar lorjuk yang lebih difokuskan pada segmen pasar tertentu. Penentuan target pasar harus benar-benar teliti agar tujuan usaha bisa tercapai. Setelah mengetahui target pasar lorjuk maka akan mudah menentukan strategi pemasaran selanjutnya.
Kondisi diatas didukung Tjiptono (1999) dalam Istri (2012) bahwa penentuan target pasar perlu memenuhi kondisikondisi tertentu yaitu : (1) dapat dijangkau (accessable) yaitu segmen pasar yang sudah dibentuk atau direncanakan belum tentu semua dapat dijangkau atau dilayani oleh perusahaan. Faktor penyebabnya antara lain hambatan perdagangan, perilaku masyarakat tertentu, perbedaan kebudayaan, hukum dan sebagainnya; (2) dapat diukur (measurable) dalam artian meskipun perilaku bagianbagian adalah homogen, tetapi dalam kenyataannya sulit untuk melakukan pengukuran perbedaan-perbedaan tersebut.; (3) memberikan keuntungan (profitable) yaitu kondisi dimana pasar yang dituju memberikan keuntungan bagi perusahaan; dan (4) dapat memberikan perbedaan maksimum dalam strategi bersaing.

Dapat disimpulkan bahwa, target pasar dipilih berdasarkan kesesuaian antara orientasi strategis perusahaan, khususnya keunggulan bersaing yang dimiliki dan sumber daya yang tersedia dengan karakteristik pasar yang hendak dituju. 


\section{Positioning " Lorjuk"}

Dari analisis data dan hasil wawancara serta kuesioner yang diperoleh dari produsen dalam hal ini adalah penjual bahwa produk lorjuk lebih disukai dan diminati oleh konsumen jika dibandingkan dengan "rung-terung"(bahasa lokal Madura) atau teripang. Meskipun dalam proses penangkapannya hampir sama yaitu samasama mencari ditepi pantai. Lorjuk memiliki kelebihan dibanding "rung-terung" dalam hal diversifikasinya. Lorjuk bisa diolah menjadi olahan kering dan dicampur dengan berbagai macam makanan yang lain. Sedangkan "rung-terung" (teripang) tidak bisa diolah menjadi berbagai olahan hanya bisa diolah menjadi kerupuk saja.

Dalam memasarkan produk lorjuk pada segmen pasar yang sudah ditentukan penting untuk diperhatikan bagaimana image atau persepsi konsumen terhadap produk yang ditawarkan. Karena itulah positioning lorjuk diperlukan dalam strategi pemasarannya. Tujuan Positioning lorjuk adalah untuk menciptakan suatu posisi tersendiri pada pasar dari para pesaingnya.

Sejalan dengan Craven (1997) strategi target pasar dan memposisikan produk dilakukan dengan jalan (1) identifikasi dan analisis segmen pada pasar produk; (2) memutuskan segmen mana yang akan dijadikan target pasar; dan (3)merancang dan mengimplemen- tasikan strategi posisikan untuk setiap segmen pasar.

Tata letak atau lay out penyajian di outlet sangat mempengaruhi daya jual suatu produk. Begitupun lay out dari lorjuk di outlet diletakkan pada bagian paling depan. Hal ini diharapkan agar konsumen dapat dengan mudah melihat lorjuk yang dijualnya, sehingga jika konsumen tidak kesulitan mencari letak lorjuk. Ada konsumen yang semula tidak berniat membeli lorjuk namun setelah melihatnya menjadi tertarik untuk membelinya.

Selain itu penjual juga meletakkan lorjuk berdampingan dengan pesaingnya yaitu sesama camilan seafood yang lain seperti "rung terung seperti pada Gambar berikut ini. Keduanya merupakan makanan camilan dan sama-sama seafood. Namun harga lorjuk lebih mahal daripada rung terung.

Penempatan lorjuk di outlet yang secara sengaja diletakkan berdampingan dengan pesaingnya yaitu rung terung bisa mempengaruhi jumlah penjualan. Karena pembeli yang tujuan utamanya membeli lorjuk saja bisa tertarik dan beralih untuk membeli " rung terung" dengan asumsi sama-sama seafood dan harganya lebih murah jika dibandingkan dengan lorjuk. Kondisi ini tidak menguntungkan bagi lorjuk atau sebaliknya.

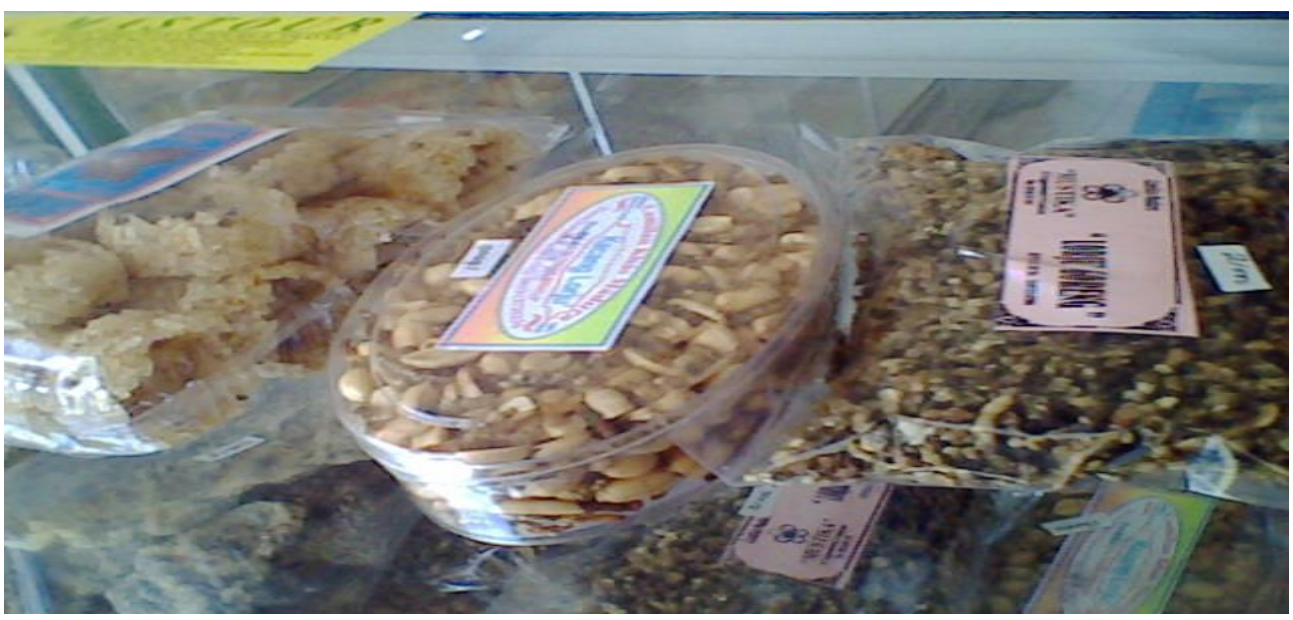

Gambar. 1. Produk lorjuk yang dipajang paling depan pada outlet 


\section{Positioning lorjuk dalam Sudut Pandang Konsumen}

Dari hasil wawancara dan kuesioner diperoleh informasi bahwa keinginan dan ketertarikan konsumen terhadap produk lorjuk lebih besar jika dibandingkan dengan teripang, meskipun sama- sama merupakan sea food dan bisa digunakan sebagai camilan.

Potisioning produk lorjuk menurut atributnya adalah bahwa dalam hal ini yang dimaksud kemasan menarik adalah labelnya bagus, tulisan bagus, warna labelnya cerah dan plastiknya tebal. Untuk ukuran kemasan adalah cukup artinya kemasan lorjuk antara 100-125 gram. Keberadaan atau lamanya stok di toko antara 1-2 minggu. Sedangkan untuk merk yang beredar harus jelas, sudah terdaftar di BPOM, mudah diingat dan dikenal.

Hal ini sesuai dengan Wahyono (2012), mengemukanan bahawa merek (brand) adalah suatu identitas yang mengkomunikasikan suatu janji dari manfaat yang diberikan suatu produk. Identitas merek diciptakan dari salah satu atau elemen-elemen berikut: nama, logo, simbol, warna, jenis huruf, desain kemasan, dan desain atau penampakan produk itu sendiri.

Positioning produk lorjuk menurut manfaat yaitu lorjuk merupakan sumber protein yang tinggi, kandungan gizinya juga tinggi dan merupakan makanan yang sehat maka konsumen atau pembelinya adalah mereka yang selalu memperhatikan kualitas makanan dan biasanya juga memperhatikan dalam hal kesehatan. Pembeli tidak asal mengkonsumsi makanan yang dimakannya sehingga lorjuk yang memiliki kandungan gizi yang baik bisa menjadi tujuan dalam memilih makanan. Lorjuk merupakan barang premium sehingga merupakan kebanggaan atau prestise jika membeli produk lorjuk ini. Hal ini bisa menunjukkan status sosial dari pembeli atau konsumen. Pada umumnya yang membeli lorjuk dengan tujuan ini adalah mereka yang memperhatikan status sosialnya.
Positioning lorjuk menurut jumlah dan frekuensi adalah biasanya konsumen yang membeli lorjuk sebanyak 5-10 bungkus frekuensinya hanya 1 kali per bulan karena mereka hanya menggunakannya sebagai oleh-oleh buat keluarga atau temannya. Sedangkan yang membeli 2-5 bungkus frekuensinya 2 kali per bulan, mereka membeli untuk dkonsumsi sendiri sebagai camilan dirumah. Dan untuk pembelian 3-6 bungkus frekuensinya 1 kali per bulan tujuan mereka hanya utuk hidangan jika ada tamu berkunjung.

Pembeli lorjuk yang digunakan untuk oleh-oleh biasanya adalah masyarakat secara umum, baik pria maupun wanita. Sedangkan jika digunakan untuk camilan dirumah ataupun hidangan tamu biasanya pembelinya adalah ibu rumah tangga. Dari data tersebut menunjukkan bahwa frekuensi dan jumlah pembelian terhadap lorjuk masih rendah.

Positioning lorjuk menurut pembeli adalah bahwa yang membeli lorjuk memiliki pekerjaan bervariasi yaitu pengusaha atau wiraswasta (yang penghasilannya diatas UMR atau UMK ) PNS, Dosen dan Guru (Golongan III keatas). Mereka mayoritas memiliki pendapatan sebesar 1-5 juta rupiah dan berdomisili baik di desa maupun dikota. Hal ini menunjukkan bahwa tidak hanya orang yang tinggal di kota saja yang mengkonsumsi lorjuk.

Harga lorjuk yang mahal akan membentuk pasar dan konsumen tersendiri, artinya hanya masyarakat yang memiliki penghasilan lebih yang biasanya membeli produk lorjuk ini. Dari data yang sudah diolah penghasilan konsumennya yaitu rata-rata adalah antara 1-5 juta rupiah. Jika dilihat UMR Kabupaten Pamekasan berdasarkan SK No. 93.Th 2010 tentang UMR Kota Pamekasan adalah sebesar Rp 1.500.00,00. (Anonymous, 2011). Dengan berpedoman terhadap UMR Kabupaten Pamekasan maka yang mampu untuk membeli lorjuk adalah masyarakat yang mempunyai pengahasilan diatas UMR 
tersebut. Sedangkan untuk PNS Golongan III keatas besar gaji adalah Rp. 2.064.100,00 dengan gaji sebesar itu maka mereka bisa membeli lorjuk karena diasumsikan bahwa mereka sudah terpenuhi kebutuhan pokoknya.

Positioning lorjuk menurut produk pesaing dalam hal ini adalah "rung terung, kripik kerang dan kol nenek" adalah bahwa lorjuk merupakan makanan yang berasal dari laut atau seafood, memiliki kandungan protein yang tinggi serta dapat didiversifikasi menjadi beberapa olahan makanan. Selain itu lorjuk biasa digunakan sebagai makanan camilan yang khas. Serta bisa juga digunakan untuk oleh-oleh ke luar kota. Dengan memperhatikan pesaing tersebut maka lorjuk harus diolah dengan baik dan benar serta disajikan dengan lebih menarik sehingga mampu bersaing dengan produk seafood lainnya.

Pada Gambar berikut ini adalah "rungterung", yang menjadi salah satu pesaing lorjuk lorjuk dengan harga yang lebih mahal jika dibandingkan dengan rung terung serta keberadaannya yang bersifat musiman dan cara mencarinya yang sulit merupakan keuntungan bagi rung terung.

Positioning lorjuk menurut diversifikasi produk yaitu lorjuk bisa diolah menjadi berbagai macam hasil pengolahan yang berbeda-beda seperti yang dapat dilihat di toko-toko camilan, supermarket. serta pemasaran produk lorjuk ini selain di dalam kota juga sudah sampai keluar kota Pamekasan. Diversifikasi produk tersebut antara lain adalah lorjuk kering, "lorjuk goreng", lorjuk campur kacang dan rengginang lorjuk.

Semua produk lorjuk harganya mahal, hal ini karena untuk mendapatkan lorjuk sangat sulit sehingga wajar jika harganya menjadi mahal, meskipun pada saat musim. Positioning lorjuk menurut kualitas dan harga yaitu jika kondisi lorjuk itu utuh maka harga lorjuk menjadi mahal, sebaliknya jika lorjuk dalam kondisi hancur maka harganyapun menjadi lebih murah.

Penentuan posisi pada produk lorjuk ini secara umum bertujuan agar konsumen mempunyai image yang khusus terhadap produk lorjuk ini.Yaitu bahwa lorjuk merupakan makanan camilan dengan harga premium. Hal ini seperti yang disampaikan oleh Istri (2010) bahwa tujuan positioning suatu produk adalah agar mengetahui image dan persepsi konsumen terhadap produk yang ditawarkan.

Strategi memposisikan produk lorjuk dapat dilakukan dengan mempromosikan manfaat yang dikandung oleh lorjuk serta penggunaan lorjuk bagi konsumen. Produsen berusaha menghasilkan beberapa produk yang memiliki karakteristik yang berbeda-beda, misalnya kualitas, ukuran, model, warna. Karena dasar pemikiran diferensiasi bahwa pelanggan memiliki selera masing-masing dan selera tersebut berubah sepanjang waktu, produsen berupaya menawarkan sebanyak produk yang bisa memenuhi semua variasi tersebut.

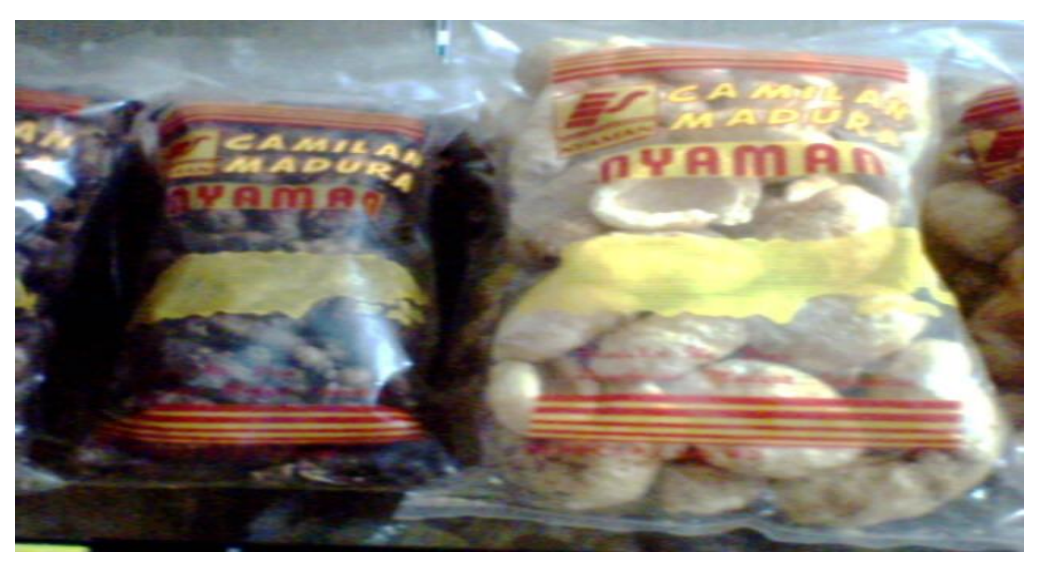

Gambar 2. Rung terung merupakan makanan camilan 


\section{Analisis Positioning Berdasarkan MDS}

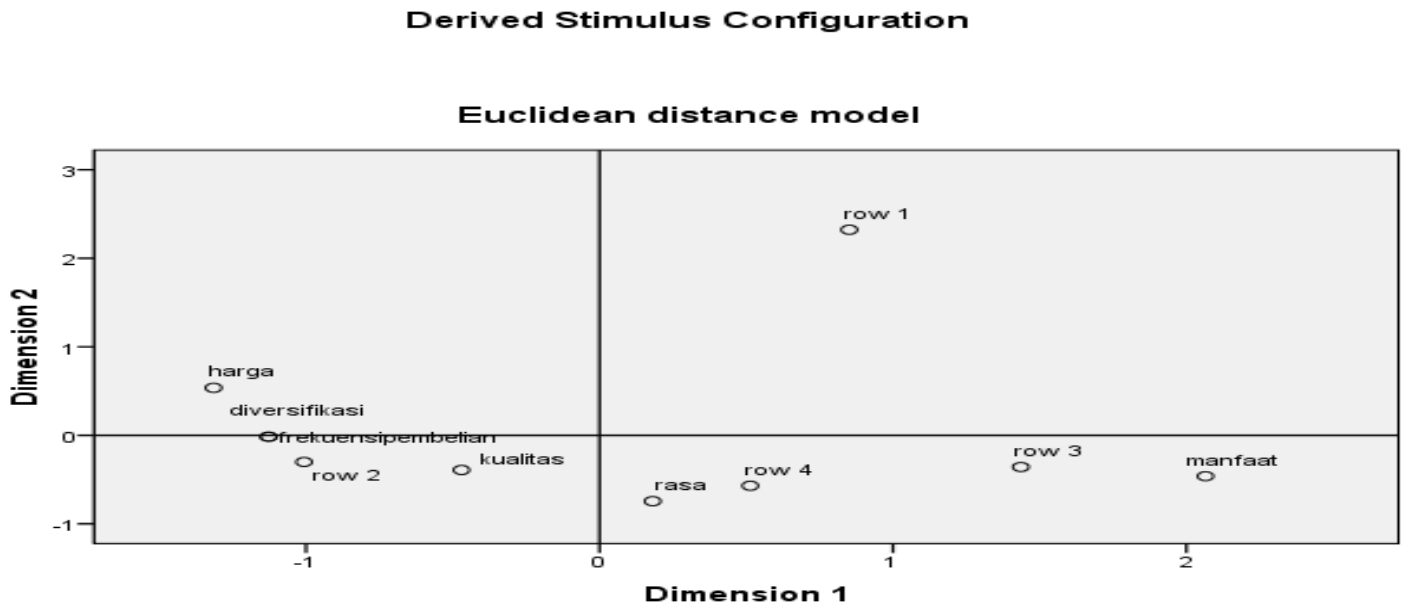

Keterangan: $1=$ lorjuk, $2=$ rungterung,3=kripik kerang,4= kol nenek.

Sumber : Data Primer Diolah (2016)

Gambar 3. Analisis MDS Lorjuk

Analisis Multidimensional Scaling (MDS) digunakan untuk menganalisis positioning lorjuk digunakan untuk memberikan gambaran visual dari kedekatan dan kesamaan lorjuk dengan makanan seafood lainnya. Analisis Multidimensional Scaling (MDS) yang digunakan dalam penelitian ini adalah untuk memposisikan lorjuk terhadap produk seafood yang lain yaitu : rung terung, kripik kerang simping dan kol nenek. Dengan asumsi bahwa rungterung, kripik kerang simping dan kol nenek merupakan makanan seafood yang memiliki kesamaan dan kemiripan dengan lorjuk. Berikut adalah hasil analisis Multidimensional Scaling (MDS) dari lorjuk terhadap rung terung, kerang dan kol nenek.

Dari hasil analisis Multidimensional Scaling (MDS) diketahui bahwa kedekatan dan kemiripan antara lorjuk, rung terung, kripik kerang simping dan kol nenek cukup dekat. Letak kuadran lorjuk, rung terung berbeda dengan letak kripik kerang simping dan kol nenek. Kripik kerang simping dan kol nenek menempati kuadran yang sama. Bila dilihat rasa, manfaat, frekuensi pembelian, diversifikasi dan kualitas maka terlihat bahwa posisinya hampir sama atau berdekatan. Sedangkan bila dilihat dari harganya lorjuk menempati posisi paling jauh dari titik tengah, hal ini menunjukkan bahwa lorjuk dan ketiga produk yang lain ada perbedaan yang cukup besar dari segi harga.

Dalam gambar diatas menunjukkan adanya beberapa atribut yang tersebar pada dua kuadran yang berbeda. Gambar diatas memberikan beberapa temuan. Pertama, gambar memberikan petunjuk bagaimana responden menilai produk lorjuk atas dasar atributnya. Apabila ditarik vektor dari sumbu ordinat tersebut atau semakin jauh jarak atribut dari sumbu ordinat maka semakin kuat atribut tersebut mencirikan sebuah produklorjuk (Istijanto,2004)

Temuan kedua dari gambar diatas menunjukkan hubungan antara atributatribut yang diteliti. Semakin dekat jarak atribut tersebut maka semakin berhubungan kedua atribut tersebut. Dari gambar atribut yang memiliki hubungan yang dekat adalah atribut manfaat dan rasa antara lorjuk, rungterung, kripik kerang dan kol nenek. Sementara atribut kualitas dan frekuensi pembelian menempati kuadran ang sama juga. Sedangkan untuk atribut difersifikasi dan harga juga pada kuadran yang sama, hal ini menunjukkan bahwa harga dan difersifikasi memberikan indikasi bahwa dari keenam atribut hanya dua atribut yang 
cukup kuat untuk mendeferensiasikan perbedaan suatu produk lorjuk dengan produk lainnya.

\section{KESIMPULAN}

Dari penelitian yang dilakukan diperoleh kesimpulan sebagai berikut:

Target pasar lorjuk adalah masyarakat yang umumnya secara geografinya bertempat tinggal di Komplek Perumahan, di kota,di desa,dalam kota Pamekasan dan luar kota. Sedangkan secara demografi target pasar lorjuk adalah masyarakat pada usia rata-rata antara 20 - 50 Th. Jenis Kelamin Perempuan dan Laki-laki. Pendidikan mayoritas mulai dari SMU sampai sarjana. Dengan tingkat penghasilan mayoritas adalah antara Rp. 1.000.000,00 Rp 5.000.000,00 per bulan.

Strategi memposisikan produk lorjuk dapat dilakukan dengan mempromosikan manfaat yang dikandung oleh lorjuk serta penggunaan lorjuk bagi konsumen. Produsen berusaha menghasilkan beberapa produk yang memiliki karakteristik yang berbeda-beda, misalnya kualitas, ukuran, model, warna. Karena dasar pemikiran diferensiasi bahwa pelang-gan memiliki selera masingmasing dan selera tersebut berubah sepanjang waktu, produsen berupaya menawarkan sebanyak produk yang bisa memenuhi semua variasi tersebut.

Positioning lorjuk menurut Analisis Coresponden sudut pandang produsen dan konsumen adalah produk lorjuk lebih disukai dan diminati oleh konsumen jika dibandingkan dengan "rung-terung", kripik kerang dan kol nenek. Berdasarkan analisis Multidimensional Scaling (MDS) adalah lorjuk memiliki posisi yang lebih tinggi dibandingkan dengan rung terung, kripik kerang dan kol nenek. Harga lorjuk paling tinggi, sehingga lorjuk memang termasuk barang premium .

\section{DAFTAR PUSTAKA}

Anonymous. (2002). Pemberdayaan Ekonomi Masyarakat Pesisir (PEMP).

Badan Busat Statistik. (2013). Kabupaten Pamekasan dalam Angka. Pamekasan

Bilson S. (2004). Riset Pemasaran. Penerbit. Gramedia Pustaka Utama. Jakarta.

Direktorat Jenderal Pesisir dan Pulau-Pulau Kecil. Departemen Kelautan dan Perikanan

(2010). Survei Sensus Ekonomi Nasional. Ditjen PPHP. Jakarta.

(2010) Menurunnya Konsumsi Siput/Kerang. 2009. Warta Pasar Ikan, Edisi Maret 2010, Volume 79. Jakarta

Cravens DW. (1997). Strategic Marketing, Richard D. Irwin, Inc.

Dahuri R, Rais J, Ginting S P dan Sitepu. (2006). Pengelolaan Sumber Daya Wilayah Pesisir dan Lautan Secara Terpadu. PT Pradnya Paramita. Jakarta

Damaijati E. (2003). Metodologi Pemilihan Agribisnis. Penerbit. UPN Press. Surabaya.

Dewi H dan Syafrizal. (2008). Analisis Segmentasi, Targeting dan positioning Program Pendidikan Magister (Studi pada Institusi Penyelenggara MM di Kota Padang). Vol. 13 No. 2 Padang

Istri A, (2010). Analisis Strategi Segmentasi, Targeting dan Positioning "Kacang Manis mentari" (UD. Murni Asih) di Kota Denpasar. Denpasar

Johan S. (2012). Diferensiasi dan Positioning Produk. <http://jurnalsdm.blogspot.com/2009/04/pernpositioning dalam strategi. html> 
Kotler Philip. (1997). Marketing Manajemen : Analysis, Planning, Implementation and Control, Jilid 1, Nineth edition, New Jersey, Prentice Hall Inte-rnational

Michael E Porter. (1994). Keunggulan Bersaing. Menciptakan dan Mempertahankan Kinerja Unggul. Penerbit Binarupa Aksara, Jakarta

Nontji A, (2005). Laut Nusantara. Penerbit Djambatan, Jakarta.
Satria A, Umbari A, Fauzi A, Purbayanto A, Sutarto E, Muchsin I, Muflikhati I, Karim M, Saad S, Oktariza W dan Imran Z. (2002). Menuju Desentralisasi Pengelolaan Sumberdaya Perikanan. Pusat Kajian Agraria IPB, Jakarta Selatan

Soekartawi. (2005). Agribisnis. Penerbit PT. Raja Grafindo Persada, Jakarta 